\title{
Sickle cell disease: chest and abdominal manifestation-A CT based study
}

\author{
Malaz Mohammed Ali Omer Ahmed ${ }^{1}$, Caroline Edward Ayad ${ }^{1}$ \\ ${ }^{1}$ (Sudan University of Science and Technology, College of Medical Radiological Science. Khartoum-Sudan )
}

\begin{abstract}
Patients with sickle cell disease (SCD) may have frequent episodes of abdominal pain and/or fever of uncertain cause. While many of these episodes represent the possibility of complications; Computed tomography (CT) was used to evaluate 67 Saudi Arabian patients with SCD .In 67 of the patients; the liver was affected in 59 patients, lungs in 56 patients, kidneys in 55 and gall bladder in 22 patients and pancreas in 5 cases. Spleen abnormalities were found to be Splenomegaly, cyst, abscess, infarction, Splenomegaly with cyst and Splenomegaly with abscess where the patient's age and SC type were considered. Hepatic abnormalities including focal necrosis, Hepatomegaly, abscess, cyst; infarction as well; Cholelithiasis, gall stones and dilated common bile duct and acute pancreatitis were also considered as an important manifestation of SCD. Renal abnormalities were found to be papillary necrosis, renal abscess, Stones with hydronephrosis, renal vein thrombosis, renal failure and renal infarction. Lungs CT manifestations were found to be pleural effusion, pneumonia, atelectasis, ground glass nodules, consolidation, fibrosis, Lung abscess. The episodes were increased by increasing of the children age at different $S C D$.

Computed tomography $(C T)$ has been shown to be an excellent modality for efficient and multisystemic evaluation of the abdomen and chest in these patients.
\end{abstract}

Keywords : Sickle cell disease, Computerizes Tomography, Saudi Arabia, manifestation.

\section{INTRODUCTION}

Sickle cell disease (SCD) is perhaps the most common of human hereditary disorders. Patients with (SCD) are frequently experience acute painful vasoocclusive crises or fever of unknown origin .Sickle cell patients are at high risk for many serious and multi systems problems causing similar signs and symptoms. [1,2]

Computed tomography (CT) has been shown to be an excellent modality for efficient and multisystemic evaluation of the abdomen. Studies using CT scan was obtained to define hepatic and splenic abnormalities associated with abdominal pain / fever [3]. CT has proved equally useful in identifying previously undiagnosed or unconfirmed retained intrahepatic calculi, interstitial nephritis, acute focal pyelonephritis, visceral perforations with intraabdominal abscesses, and other complications of SCD.

SCD is caused by mutation in the b-globin chain, causing the hydrophilic glutamic acid to be replaced with the hydrophobic amino acid Valine. The association of two a-globin subunits with two mutant b-globin subunits forms hemoglobin $\mathrm{S}(\mathrm{Hb} \mathrm{S})$. Under environmental low oxygen concentrations, this mutant hemoglobin will cause aggregation of hemoglobin molecules. These will distort RBCs into a sickle shaped .Consequently, these deformed RBCs fail to pass smoothly through the narrow capillaries, leading to vessel occlusion and ischemia $[4,5]$

There are different forms of the disease: In homozygous pattern (Hb SS), the blood will have no normal hemoglobin particles and phenotypically termed sickle cell anemia (SCA). Heterozygous genotype, in which the patient inherits a sickle cell gene from one parent and a normal gene from the other parent forming $\mathrm{Hb} \mathrm{SA}$, is phenotypically expressed as sickle cell trait. Also, other heterozygous types of $\mathrm{Hb} \mathrm{S}$ may form due to combination with another different abnormal gene, such as sickle-hemoglobin C disease (Hb SC) or Hb S-beta thalassemia (Hb S-tha).[6] In Hb SS patients, severe anemia is caused by excessive destruction of the red cells. The bone marrow rate of hematopoiesis is significantly increased, but does not match the rate of destruction. In sickle trait patients with $\mathrm{Hb} \mathrm{SA}$, there is no severe hemolytic crisis as SCA patients. They may have symptoms only if they are severely deprived of oxygen [7]

The statistics of SCD in the open literature showed that (SCA) affects millions throughout the world. It is particularly common among sub-Saharan Africa population as well; Saudi Arabia; India; and Mediterranean countries. In the Unites States, it affects around 72,000 people, most of whose ancestors come from Africa. The disease occurs in 1 in 12 African Americans; carry the sickle cell trait [8]. SCD in Saudi Arabia is considered one of the major public health problems in the Eastern province. $[9,10]$

This research study tries to cover most of the radiological manifestations, in different systems affected by the disease, as organ-based approach in Saudi Arabian patients. Systems are arranged as according to the frequency: including spleen changes which occur in 67 of the patients, liver was affected in 59 patients, lungs in 56 
patients, pancreas in 5, kidneys in 55 and gall bladder in 22 patients, and were presented and evaluated according to age of the patients and type of SCA as we encountered in practice.

\section{MATERIALS AND METHODS}

\subsection{Place and duration of the study:}

This study was done at Ballasmar General Hospital and Fahad King Hospital CT departments, in Aseer and Gizan states (South Of Saudi Arabia).Data were collected in the period spanned from June2014 up to June2016.The present study was approved by the Ethics Committee of the Research council, College Of Medical Radiological Science as well as the approval Of the Radiology Departments. Verbal consent was obtained from all potential participants. The aims, benefits of the present study were explained to all participants in details. Medical history of all study subjects were thoroughly reviewed directly from participants themselves or from their parents and those with conditions that may in any way, alter the findings of the current study were excluded.

\subsection{Study population:}

A sample of (67) patients who were investigating as sickle cell anemia disease, undergo for abdomen CT examination complain of abdominal pain and/or unexplained fever. Patient's data were registered .28 patients were females, while the 39 were males and their ages are ranged from 10 months to 28 years old. The patients who were affected with sickle cell anemia were from different Saudi Arabian areas.

\subsection{Machine used:}

General Electric (GE) Hi-speed 60 multidetector CT scanner was used, made by GE Healthcare Manufacturer(2009).With the following specifications, Tube 2.0 MHU MX 135, 3.9 million mAs, Software level 6.03, Fast scan $1.0 \mathrm{sec}$, Helical plus, 3D max, Power $200 \mathrm{~mA}$, Max 1 mm thickness, Acquisition, Helical 60 Max, Smart pre, DICOM MOD. It has voltage from 70- $150 \mathrm{Kvp}$ and four options of mA, High (110), medium (77), low (55), and extra low (22).And has three options of slice thickness: $1 \mathrm{~mm}, 3 \mathrm{~mm}$ and $5 \mathrm{~mm}$. Similar scan interspaces, has scan time of $4.8 \mathrm{sec}$, and construction algorithm of normal option (soft tissue), high frequency (bony)and HRCT (for lungs)Images given in CD drive and store in special packs system of the hospital.

\subsection{Technique used}

Two types of scanning techniques were used, for adults and other for pediatrics. CT scans typically obtained for visualizing all abdominal organs and included axial, coronal and/or sagittal cuts. As well the chest was also been scanned .

\subsubsection{Technique used in pediatric: (from $0-12$ years)}

Sedation was used for patient between ages of 6 months and 5 years. They are given IV pentobarbital sodium, $5 \mathrm{mg} / \mathrm{kg}$ to a maximum dose of $200 \mathrm{mg}$.For patient under 5 years old; a comfortable device for immobilization was used that secures patient's arms beside the head with adhesive straps. For larger children, we used adhesive straps putted under the mattress and over the patient.

Scanning protocols were obtain with patient supine, feet first, patient centered with gantry and scan taken from lower chest to symphsis pubic. The chest was scanned from sternal notch to lower costal margin. Thinner slices of $5 \mathrm{~mm}$ used for children 2 years and under $10 \mathrm{~mm}$ slice for children 3 years and older. A $120 \mathrm{kvp}$ with $\mathrm{mA}$ ranged from 150-230 mA was used. Higher pitch of 1 to 2 was used to reduce patient dose, and window of soft tissue was chosen. A plain axial sections (sections before contrast) was taken firstly. The non sedated patients were given dilute Hypaque Sodium which has concentration of $40 \%$ to drink immediately before examination. The amount of oral contrast needed per patients was determining by ages as follow: From 6 months to 1 year given $175 \mathrm{ml}$, from $1-5$ years $250 \mathrm{ml}$ and from $6-12$ years given $500-700 \mathrm{ml}$ were given. IV contrast agent was also given: $1-2 \mathrm{ml} / \mathrm{sec}$ Omnipaque through automatic injector just before examination and three stages of scanning were taken. Early arterial phase, venous phase and delayed venous phase

\subsubsection{Techniques which used in adults: (over 12years)}

Scans were obtained with patient supine, feet first, patient centered and instructed to be hold his/her breathe at end of inspiration. Scan ranged from lower of the chest to iliac crest, The chest was scanned from sterna notch to lower costal margin and thinner slices of 1,2 to $4 \mathrm{~mm}$ collimation with 1,2 to $4 \mathrm{~mm}$ intervals are used.Rotation time was $0.5 \mathrm{sec}$ with pitch of $1.37 \mathrm{and} \mathrm{kv}$ of 120 with auto $\mathrm{mA}$ range $100-400$ and the table feed interval was $27.5 \mathrm{~mm}$. Window setting which used to display images was for evaluation of soft tissue, window width (ww) of 350-400 Hounsfield unit (HU) and window level (Wl) of 35-50 HU. Images are reconstructed in coronal and/or sagittal planes. Used very thin slice $(1 \mathrm{~mm})$ to be reconstructed to serve as source images for coronal and/or sagittal reformatted images. A plain axial sections (sections before contrast) was taken firstly. Dilute Barium Sulfate solution (350-500)ml of contrast media was given to drink immediately before examination. Intravenous contrast agent was obtained, $(2$ to $6 \mathrm{ml})$ of Omnipaque per second with concentration of $60 \%$ was given to the patient just before examination by automatic injector, and three stages of scanning were obtained .The early one was arterial phase scan with typical scan delays of 20-30sec, The later venous phase scans with delays of $60-80 \mathrm{sec}$ and the last one is delayed scans 1 to 4 hours. 


\subsection{Images evaluation:}

All images were evaluated by two radiologist and three technologist, and all patients were evaluated to identify any changes occurred within abdominal organ and lower chest as a complication of sickle cell anemia. The study classified the changes on some abdominopelvic organs .Changes were found in the spleen of 67 patients, liver was affected in 59 patients, lungs in 56 patients, pancreas in 5, kidneys in 55 and gall bladder in 22 patients

\subsection{Data Analyses:}

Data were analyzed using Excel programme .The data obtained were analyzed statistically and data were presented as frequencies.

\section{RESULTS}

Abdomen and Chest manifestation was evaluated spleen changes occur in 67 of the patients, liver was affected in 59 patients, lungs in 56 patients, kidneys in 55 and gall bladder in 22 patients, pancreas in 5 cases.

Table1 cross tabulation between patients' age and spleen CT manifestation in SCA

\begin{tabular}{|c|c|c|c|c|c|c|}
\hline Age classes & Splenomegaly & $\begin{array}{c}\text { Splenic } \\
\text { cyst }\end{array}$ & $\begin{array}{c}\text { Splenic } \\
\text { Abscess }\end{array}$ & $\begin{array}{c}\text { Splenic } \\
\text { infarction }\end{array}$ & $\begin{array}{c}\text { Splenomegal with } \\
\text { cyst }\end{array}$ & $\begin{array}{l}\text { Splenomegaly with } \\
\text { abscess }\end{array}$ \\
\hline 3 mon $-7 \mathrm{y}$ & 15 & 3 & - & 3 & 1 & 6 \\
\hline $8 \mathrm{y}-17 \mathrm{y}$ & 6 & 2 & 4 & 9 & 1 & 1 \\
\hline $18 \mathrm{y}-28 \mathrm{y}$ & 2 & 0 & 1 & 11 & 0 & 2 \\
\hline & 23 & 5 & 5 & 23 & 2 & 9 \\
\hline
\end{tabular}

Table 2cross tabulation between patients' age and liver CT manifestation in SCA

\begin{tabular}{|c|c|c|c|c|c|c|}
\hline Age classes & Normal & Focal Necrosis & Hepatomegaly & $\begin{array}{c}\text { Hepatic } \\
\text { Abscess }\end{array}$ & $\begin{array}{c}\text { Hepatic } \\
\text { Cyst }\end{array}$ & $\begin{array}{c}\text { Hepatic } \\
\text { Infarction }\end{array}$ \\
\hline 3 mon $-7 \mathrm{y}$ & 4 & 3 & 12 & 3 & 5 & 1 \\
\hline $8 \mathrm{y}-17 \mathrm{y}$ & 4 & 2 & 5 & 5 & 4 & 3 \\
\hline $18 \mathrm{y}-28 \mathrm{y}$ & 0 & 3 & 2 & 4 & 1 & 6 \\
\hline Total & 8 & 8 & 19 & 12 & 10 & 10 \\
\hline
\end{tabular}

Table 3 cross tabulation between patients' age and lungs CT manifestation in SCA

\begin{tabular}{|c|c|c|c|c|c|c|c|c|}
\hline Age classes & Normal & $\begin{array}{c}\text { Pleural } \\
\text { effusion }\end{array}$ & Pneumonia & $\begin{array}{c}\text { Atelec- } \\
\text { tasis }\end{array}$ & $\begin{array}{c}\text { Ground } \\
\text { glass } \\
\text { nodules }\end{array}$ & $\begin{array}{c}\text { Consolid } \\
\text {-ation }\end{array}$ & fibrosis & $\begin{array}{c}\text { Lung } \\
\text { abscess }\end{array}$ \\
\hline 3 mon-7y & 8 & 9 & 5 & 3 & 1 & 2 & 0 & 0 \\
\hline $8 \mathrm{y}-17 \mathrm{y}$ & 3 & 3 & 1 & 1 & 4 & 5 & 2 & 4 \\
\hline $18 \mathrm{y}-28 \mathrm{y}$ & 0 & 4 & 0 & 0 & 0 & 1 & 8 & 3 \\
\hline & 11 & 16 & 6 & 4 & 5 & 8 & 10 & 7 \\
\hline
\end{tabular}

Table4 cross tabulation between patients' age and kidney CT manifestation in SCA

\begin{tabular}{|c|c|c|c|c|c|c|c|}
\hline Age classes & Normal & $\begin{array}{c}\text { Papillary } \\
\text { necrosis }\end{array}$ & $\begin{array}{c}\text { Renal } \\
\text { abscess }\end{array}$ & $\begin{array}{c}\text { Stones } \\
\text { \&hydronephrosis }\end{array}$ & $\begin{array}{c}\text { Renal vein } \\
\text { thrombosis }\end{array}$ & $\begin{array}{c}\text { Renal } \\
\text { failure }\end{array}$ & $\begin{array}{c}\text { Renal } \\
\text { infarction }\end{array}$ \\
\hline 3 mon $-7 \mathrm{y}$ & 8 & 9 & 2 & 8 & 1 & 0 & 0 \\
\hline $8 \mathrm{y}-17 \mathrm{y}$ & 4 & 4 & 5 & 2 & 2 & 1 & 5 \\
\hline $18 \mathrm{y}-28 \mathrm{y}$ & 0 & 2 & 0 & 1 & 1 & 6 & 6 \\
\hline & 12 & 15 & 7 & 11 & 4 & 7 & 11 \\
\hline
\end{tabular}

Table5 cross tabulation between patients' age, gall bladder and pancreas CT manifestation in SCA

\begin{tabular}{|c|c|c|c|}
\hline Age classes & Cholelithiasis & $\begin{array}{c}\text { Gall stones and dilated common } \\
\text { bile duct }\end{array}$ & $\begin{array}{c}\text { Acute } \\
\text { pancreatitis }\end{array}$ \\
\hline 3 mon $-7 \mathrm{y}$ & 0 & 3 & 0 \\
\hline $8 \mathrm{y}-17 \mathrm{y}$ & 3 & 5 & 2 \\
\hline $18 \mathrm{y}-28 \mathrm{y}$ & 4 & 7 & 3 \\
\hline & 7 & 15 & 5 \\
\hline
\end{tabular}


Table6 Relation between spleen CT manifestation in SCA and type of SCA

\begin{tabular}{|c|c|c|c|c|c|c|}
\hline Type of SCA & Splenomegaly & $\begin{array}{c}\text { Splenic } \\
\text { cyst }\end{array}$ & $\begin{array}{c}\text { Splenic } \\
\text { Abscess }\end{array}$ & $\begin{array}{c}\text { Splenic } \\
\text { infarction }\end{array}$ & $\begin{array}{c}\text { Splenomegaly } \\
\text { with cyst }\end{array}$ & $\begin{array}{c}\text { Splenomegaly } \\
\text { with abscess }\end{array}$ \\
\hline Hb SS & 21 & 3 & 3 & 13 & 2 & 8 \\
\hline Hb SC & 0 & 2 & 1 & 5 & 0 & 0 \\
\hline Hb SB 0-thalassemia & 0 & 0 & 0 & 4 & 0 & 0 \\
\hline Hb SB+ thalassemia & 2 & 0 & 1 & 1 & 2 & 0 \\
\hline & 23 & 5 & 5 & 23 & 2 & 9 \\
\hline
\end{tabular}

Table7 Relation between liver CT manifestation in SCA and type of SCA

\begin{tabular}{|c|c|c|c|c|c|c|}
\hline Type of SCA & Normal & $\begin{array}{c}\text { Focal } \\
\text { necrosis }\end{array}$ & hepatomegaly & $\begin{array}{c}\text { Hepatic } \\
\text { abscess }\end{array}$ & $\begin{array}{c}\text { Hepatic } \\
\text { cyst }\end{array}$ & $\begin{array}{c}\text { Hepatic } \\
\text { infarction }\end{array}$ \\
\hline Hb SS & 7 & 4 & 17 & 5 & 7 & 5 \\
\hline Hb SC & 1 & 1 & 0 & 4 & 2 & 3 \\
\hline Hb SB 0-thalassemia & 0 & 3 & 1 & 1 & 1 & 1 \\
\hline Hb SB+ thalassemia & 0 & 0 & 1 & 2 & 0 & 1 \\
\hline & 8 & 8 & 19 & 12 & 10 & 10 \\
\hline
\end{tabular}

Table8 Relation between lung CT manifestation in SCA and type of SCA

\begin{tabular}{|c|c|c|c|c|c|c|c|c|}
\hline Type of SCA & Normal & $\begin{array}{c}\text { Pleural } \\
\text { effusion }\end{array}$ & $\begin{array}{c}\text { Pneum } \\
\text { onia }\end{array}$ & $\begin{array}{c}\text { Atelectasi } \\
\text { s }\end{array}$ & $\begin{array}{c}\text { Ground } \\
\text { glass } \\
\text { nodules }\end{array}$ & Consolidation & $\begin{array}{c}\text { fibrosis } \\
\text { Lung } \\
\text { absces } \\
\text { s }\end{array}$ \\
\hline Hb SS & 9 & 13 & 6 & 4 & 3 & 6 & 5 & 3 \\
\hline Hb SC & 1 & 2 & 0 & 0 & 1 & 1 & 2 & 2 \\
\hline Hb SB0-thalassemia & 1 & 1 & 0 & 0 & 0 & 0 & 2 & 1 \\
\hline Hb SB+ thalassemia & 0 & 0 & 0 & 0 & 1 & 1 & 1 & 1 \\
\hline & 11 & 16 & 6 & 4 & 5 & 8 & 10 & 7 \\
\hline
\end{tabular}

Table9 Relation between kidney CT manifestation in SCA and type of SCA:

\begin{tabular}{|c|c|c|c|c|c|c|c|}
\hline Type of SCA & Normal & $\begin{array}{c}\text { Papillary } \\
\text { necrosis }\end{array}$ & $\begin{array}{c}\text { Renal } \\
\text { abscess }\end{array}$ & $\begin{array}{c}\text { Stones } \\
\text { \&hydro } \\
\text { nephrosis }\end{array}$ & $\begin{array}{c}\text { Renal vein } \\
\text { thrombosis }\end{array}$ & $\begin{array}{c}\text { Renal } \\
\text { failure }\end{array}$ & $\begin{array}{c}\text { Renal } \\
\text { infarction }\end{array}$ \\
\hline Hb SS & 10 & 13 & 5 & 8 & 3 & 4 & 6 \\
\hline Hb SC & 1 & 1 & 1 & 1 & 1 & 2 & 2 \\
\hline Hb SB 0-thalassemia & 1 & 0 & 0 & 1 & 0 & 1 & 2 \\
\hline Hb SB+thalassemia & 0 & 1 & 1 & 1 & 0 & 0 & 1 \\
\hline & 12 & 15 & 7 & 11 & 4 & 7 & 11 \\
\hline
\end{tabular}

Table10 Relation between gall bladder CT manifestation in SCA and type of SCA

\begin{tabular}{|c|c|c|c|}
\hline Type of SCA & Cholelithiasis & Gall stones and dilated common bile duct & Acute pancreatitis \\
\hline Hb SS & 5 & 13 & 4 \\
\hline Hb SC & 1 & 1 & 1 \\
\hline Hb SB 0-thalassemia & 0 & 1 & 0 \\
\hline Hb SB+ thalassemia & 1 & 0 & 0 \\
\hline & 7 & 15 & 5 \\
\hline
\end{tabular}

1

\section{DISCUSSION}

Splenomegaly is the commonest changes that may occur in the Saudi children sample followed by spleen infarction as seen in table (1). It should be considered that the CT appearance of the spleen largely depends on the timing of intravenous bolus administration of contrast material. The spleen may demonstrate heterogeneous enhancement during the first minute after initiation of intravenous administration of contrast material because of the different rates of flow through the cords of the red and white pulp. [11-14] This heterogeneity is itself variable in appearance; patterns include arciform , focal, and diffuse heterogeneity. [11] Therefore familiarity with these enhancement characteristics minimizes the chance that artifacts will be mistaken for disease. This is what was considered in our study during examining the patients. 
Sickle cell clots cause ischemic vascular occlusion, which frequently affects different parts of the abdominal structures. The most commonly involved organ is the spleen, which was affected in almost all patients with SCA.[15,16] Studies showed that one of developing cause of splenomegaly is acute splenic sequestration. At clinical examination, patients demonstrate massive splenic enlargement and peripheral areas of decreased attenuation with areas of increased attenuation secondary to acute hemorrhage. [17]Similarly our study showed the findings of Splenomegaly in 23 cases, Splenic cyst in 5 cases Splenic Abscess in 5 cases Splenic infarction in 23cases and splenomegaly with cyst and splenomegaly with abscess in 2 and 9 cases respectively this was presented in table $(1,6)$ where the patients age and SC type was considered .The literature have mentioned that repeated splenic infarctions that start within the first 18-36 months of life, in association with the dates of disappearance of protective $\mathrm{Hb} \mathrm{F}$, result in hyposplenism and asplenism. Splenic atrophy is a major etiology of compromised immune status and increased susceptibility to infections. [15,16]

In our study the cases of splenic infarction depends on the timing of imaging and the size of the infarct. Contrast enhanced CT scan is proved to be the most sensitive tool of imaging. The typical infarct is seen as a hypo dense non- or poorly enhancing wedge, with apex pointing toward the hilum. Similar studies showed that in late period of time infarctions may resolved completely or leave a permanent scar, or liquefy with possible abscess formation. Also, multiple small infarcts or global infarct of the whole spleen are reported in the imaging findings $[18,19,20]$

Table (2) cross tabulated the patients' age and liver CT manifestation in SCA. Focal necrosis was found in 8 cases, hepatomegaly in 19, and hepatic abscess in 12 cases, hepatic cyst in 10 and Hepatic Infarction in 10 cases. Cholelithiasis, gall stones and dilated common bile duct and acute pancreatitis were also considered as an important manifestation of SCD and was found in 7, 15 and 5 cases in respectively and was increased by increasing of the children age as presented in table 5.On the other hand in previous studies; liver infarction in SCD was reported. Acute sickle hepatic crisis affects about $10 \%$ of patients admitted for painful crisis. It usually simulates acute cholecystitis with right upper quadrant pain, fever and leucocytosis, however unlike cholecystitis; the liver is enlarged and tender and also diagnosed by CT which is considered the most sensitive imaging tool for the diagnosis of these insults [21,22]

Studies showed that a high incidence of gall bladder multiple pigmented gall stones is clearly demonstrated among SCA patients due to high bilirubin levels. [23] .Table (10) classifies the findings according to SCD types.

Table (4) showed the renal manifestation in SCA. It was found to be papillary necrosis in 15 cases ,renal abscess in 7 cases, stones with hydronephrosis in 11 cases, renal vein thrombosis in 4 cases, renal failure in 7 and renal infarction in 11 cases considering the patients age and type of SCD as presented also in table (9) .Other similar studies showed that there are multiple renal abnormalities associated with SCD including medullary renal tubular dysfunction, hematuria and papillary necrosis .[24] Glomerulu hypertrophy may be noted, which may account for the mild diffuse renal enlargement, focal or diffuse renal infection or infarction, nephrotic syndrome is less common but may be seen with renal vein thrombosis [25]. Other studies have mentioned that Sickle cell nephropathy is another debilitating complication of SCA, which develops as a result of sickling of RBCs in renal circulation. This leads to ischemia causing cortical infarctions and papillary necrosis, as well as renal tubular injury. It may be associated with complications and finally renal failure. Also, there is a possible bacterial infection of the scarred renal tissues and functional tubule abnormalities in conjunction with the compromised immunity, leading to abscess formation [26,27]

Table(3) presented the lungs CT manifestation in SCA : pleural effusion, pneumonia ,atelectasis, ground glass nodules ,consolidation, fibrosis lung abscess which was found in different ages as well; at all types of SCD including $\mathrm{Hb} \mathrm{SS}, \mathrm{Hb} \mathrm{SC}, \mathrm{Hb} \mathrm{SB} 0$-thalassemia , $\mathrm{Hb} \mathrm{SB}+$ thalassemia that are presented in table( 8)

Similar studies have mentioned that the acute chest syndrome is one of the most common causes of hospitalization and even death of SCA patients, pulmonary vascular obstruction. [28] and pleural effusion may also be seen, [29,30] Patients with SCA may develop obstructive or restrictive lung diseases, when there is a progressive decline in the pulmonary functions .This may be explained by established fibrotic lung changes from repeated episodes of pulmonary infective and vaso-occlusive events. High resolution CT scan (HRCT) shows these interstitial changes, that are of reticular or reticulonodular pattern and may be associated with traction bronchiectasis [31]

\section{CONCLUSION}

Regarding our findings and the study results, the SCD can cause multiple manifestations in the chest and abdomen; Computed tomography (CT) has been shown to be an excellent modality for efficient and multisystemic evaluation of the abdomen and chest in these patients. 


\section{Acknowledgements}

We sincerely thank the participants without whom the study would not have been feasible. The Sudan University of Science and Technology, College of Medical Radiological Science and Radiology Department in Ballasmar General Hospital and Fahad King Hospital CT departments, in Aseer and Gizan states (South Of Saudi Arabia) are thankfully acknowledged.

\section{REFERENCES}

[1]. Beeson PB, McDermott W, Wyngaanden JB. Cecil textbook of medicine. 15th ed. Vol. 2. Philadelphia: Saunders, 1979.

[2]. Williams WJ, Beutlen E, Erspen AJ, Rundles RW. Hematology. New York: McGraw- Hill, 1977.

[3]. Magid D, Fishman EK, Siegelman 55. Computed tomography of the spleen and liver in sickle cell disease. AJR 1984; 143:245249.

[4]. Bunn HF. Pathogenesis and treatment of sickle cell disease. N Engl J Med 1997;337:762-9.

[5]. <https://en.m.wikipedia.org/wiki/Sickle-cell_disease>.

[6]. Santos MN, Bezerra MA, Domingues BL, Zaccariotto TR,Oliveira DM, Costa FF, et al. Genet Test Mol Biomarkers 2011;15(10):709-13. http://dx.doi.org/10.1089/gtmb.2010.0235.

[7]. Ejindu Vivian C, Hine Andrew L, Mashayekhi Mohammad,Shorvon Philip J, Misra Rakesh R. Musculoskeletal manifestations manifestations of sickle cell disease. RadioGraphics 2007;7:1005-21

[8]. Bethesda MD. Sickle cell anemia: who is at risk? Nat Inst Health,Nat Heart, Lung, Blood Inst 2009, http://www.nhlbi.nih.gov/ health/dci/Diseases/Sca/SCA WhoIsAtRisk.html:http://

[9]. Www.nhlbi.nih.gov/health/dci/Diseases/Sca/SCA_WhoIsAtRisk.html

[10]. El-Hazmi MA. Clinical and haematological diversity of sickle cell disease in Saudi children. J Trop Pediatr 1992;38:106-12.

[11]. Jastaniah Wasil. Epidemiology of sickle cell disease in Saudi Arabia. Ann Saudi Med 2011;31(3):289-93

[12]. Donnelly LF, Foss JN, Frush DP, Bisset GS, III. Heterogeneous splenic enhancement patterns on spiral CT images in children: minimizing misinterpretation. Radiology 1999; 210:493-497.

[13]. Glazer GM, Axel L, Goldberg HI, Moss AA. Dynamic CT of the normal spleen. AJR 1981; 137:343-346.

[14]. Partanen K, Soimakallio S, Kivimäki T, Syrjänen K, Kormano M. Dynamic topography of the contrast enhancement of the spleen. Eur J Radiol 1984; 4:101-106.

[15]. Urban BA, Fishman EK. Helical CT of the spleen. AJR 1998; 170:997-1003.

[16]. Claster S, Vichinsky E. First report of reversal of organ dysfunction in sickle cell anemia by the use of hydroxyurea. Splenic Regeneration 1996;88:1951-3.

[17]. Manish Parikh, John Geibel Lewis J. Kaplan, Lewis J. Kaplan,et al. Splenic Infarct Treatment \& Management. <http://emedicine.medscape.com/article/193718-treatment\#a28>. Updated:Apr 4, 2012

[18]. Emery KH. Splenic emergencies. Radiol Clin North Am 1997; 35:831-843.

[19]. Michael R. Federle, R. Brooke Jeffrey, Terry S. Desser, Venkata Sridhar Anne, et al. Vascular disorder Splenic infarct. Diagnostic Imaging Abdomen. PART I GI Tract and Abdominal Cavity. Section 6 Spleen: 373-340; Amirsys 2004.

[20]. Morishima Aki, Schofer Joel M, Pelletier Pierre, McKee James M. Images in emergency medicine: splenic infarction due to sickle cell trait after climbing Mt. Fuji. West J Emerg Med 2008;9(3):179.

Behrang Amini. Splenic Abscess after Infarction. <http://roentgenrayreader.blogspot.com/>. Thursday, September 9, 2010. Gauthier N, Cornud F, Vissuzaine C. Liver infarction in sickle cell disease. AJR 1985;144:1089-90, 10.2214/ajr.144.5.1089.

$[21]$.

[22]. Michael R. Federle, Brooke R. Jeffrey, Terry S. Desser, Venkata Sridhar Anne, et al. Diagnostic Imaging Abdomen. PART II Hepatobiliary and Pancreas. Section 1 Liver: Vascular disorder: Hepatic infarct. 373-340; Amirsys 2004.

[24]. Eric H. Krau. Anthony D. Villella. Chronic Conditions of Sickle Cell Anemia.
$<$ http://www.netwellness.org/healthtopics/sicklecell/sicklecellchronicconditions.cfm>. Jul 10, 2009.

[25]. Morgan AG, Sergeant GR. Renal function in patients over 40 with homozygous sickle- cell disease. Br Med J 1981; 282:1181- 1183.

[26]. Buckalew VM, Somenen A. Renal manifestations of sickle cell disease. Arch Intern Med 1974; 133:660-669.

[27]. PIatt1 Joel F, Ellis James H, Rubin Jonathan M, DiPietro Michael A, Sedman Aileen B. Intrarenal arterial doppler sonography in patients with nonobstructive renal disease: correlation of resistive index with biopsy findings. AJR 1990;154:1223-7.

[28]. Platt JF, Rubin JM, Ellis JH, DiPietro M. Duplex Doppler US of the kidney: differentiation of obstructive from non-obstructive dilatation.

[29]. Aaron W. Bernard, Zahida Yasin, Arvind Venkat, M. Acute Chest Syndrome of Sickle Cell Disease. <http://www.turnerwhite. com/memberfile.php?PubCode $=$ hp jan07_sickle.pdf $>$.

[30]. Godeau B, Schaeffer A, Bachir D, et al. Bronchoalveolar lavage in adult sickle cell patients with acute chest syndrome: value for diagnostic assessment of fat embolism. Am J Respir Crit Care Med 1996;153(5):1691-6.

[31]. Ademola Emmanuel Fawibe, Philip Manman Kolo, James Ayodele Ogunmodede, Olufemi Olumuyiwa Desalu, Kazeem Alakija Salami. Advanced sickle cell associated interstitial lung disease presenting with cor pulmonale in a Nigerian. Niger Med J 2012;53(2):105-7. 